\title{
THE FUNCTIONAL/COGNITIVE PRINCIPLE OF INFORMATION STRUCTURE IN TEXTS: DISCOURSE PRESSURES AND SYNTACTIC DEVICES FOR ENGLISH AS L2 LEARNERS
}

\author{
Adriana Maria Tenuta* \\ Ana Larissa Adorno Marciotto Oliveira* \\ Federal University of Minas Gerais \\ Belo Horizonte, MG, Brazil
}

\begin{abstract}
This paper presents the results of a study carried out to investigate the degree of perception of the thematic structure of the clause (theme and rheme) and the informational structure of a text (given and new elements) by Brazilian learners of English, undergraduate students from a Federal University in Brazil. The theoretical background relies on the principles of functional-cognitive linguistics, relative to how discourse impacts linguistic choices (HALLIDAY 1985; CHAFE 1995). The corpus of this research consisted of a series of exercises that were administered to undergraduate students, English majors. The findings shed light to the fact that learners are still unaware of most processes involving grammar arrangements and the discourse flow, as they are not also very conscious of how grammar can impact the communicative intent of a written text.
\end{abstract}

Key words: Theme and rheme. Given and new. Discourse.

1 STUDY OVERVIEW

This paper aims at presenting the results of a research carried out with the objective of investigating whether learners of English as a second language recognized, implicitly and/or explicitly, the existence of the functional/cognitive principle of information distribution in texts. The research also checked the mastering, by these students, of a few syntactic devices related to the information and thematic structures, which are used to meet communicative demands. All this process reflects the relation between language and cognition through processes of attention and focus.

We checked how equipped students are to meet discourse communicative demands by making contextually adequate syntactic arrangements in clauses. We also focused on the issue of how conscious learners are of the fact that there is an information structure, which involves the concepts of old and new information, as well as there is a thematic structure, encompassing the concepts of theme and rheme in texts.

\footnotetext{
* Doctor in Linguistic Studies, Graduate Program in Linguistics and Applied Linguistics. Email: atenuta@gmail.com.

* Doctor in Linguistics Studies, Graduate Program in Linguistics and Applied Linguistics. adornomarciotto@gmail.com.
} 
To do that, a research was first carried out by Tenuta (2001) that had FALE/UFMG ${ }^{1}$ undergraduate students of Languages (English majors), at an intermediate level, as research subjects. Now, we have replicated the research, in the same educational context, in order to have a longitudinal perspective of the situation investigated. The corpus of the research consisted, in both phases, of a series of exercises administered to the undergraduate students in order to find out whether students recognized the principle of information distribution and were able to metalinguistically state it in terms of given and new elements in alternation in the discourse flow. This principle is mentioned in Rutherford (1987) and it represents the patterns of thematic structuring presented by MacCarthy (1991). Therefore, the exercises administered to students aimed at checking the general perception of the necessity of moving some components of the clause in order to meet particular discourse demands, as well as investigating the degree of students' awareness of the fact that the same propositional content of a clause can be expressed through different nominal and verbal structures, for example, by having syntactic subjects performing different thematic roles. Another point of investigation was some aspects of the learners' interlanguage, according to Rutherford (1987). Both Tenuta (2001) and this present study checked if the characteristics mentioned by Rutherford were a reality concerning our students. Tenuta (2001) investigated 39 learners, while the present study analyzed the production of 46 learners.

It is our claim in this study that learners of English as a second language, now, as they did in 2001, have little awareness of the interplay of syntax and discourse, i.e., they are not aware of the functional/cognitive principle of information structure that governs text arrangement. Also, they do not know much about the syntactic possibilities for clause arrangements intended to meet discourse demands.

In the next section, we will present and discuss the concepts of information and thematic clause structure. We will also deal with the cognitive notion of attention, which is of particular interest for this study.

\section{THE INFORMATION AND THEMATIC STRUCTURES IN THE CLAUSE}

Pieces or chunks of information in a written text are organized in terms of new and old elements. Information structure, in the functional theoretical framework to language studies, is seen as a process of interaction between what is known and what is new to language users (PRINCE, 1981; HALLIDAY, 1985, 2004). The concepts of old and new, in this context, relate, respectively, to information that is recoverable from the context (verbal or non-verbal), and information that is not recoverable. These concepts were also discussed in Rutherford (1987) to explain possibilities for learners' discourse, as a means to better reach specific communication goals.

In this framework of analysis, information structure is related to thematic structure. The elements of the thematic structure are theme, the starting point of the sentence, and rheme, the rest of the sentence. Considering Halliday's (1985, 2004)

\footnotetext{
${ }^{1}$ Faculdade de Letras/Universidade Federal de Minas Gerais, in Belo Horizonte, Brazil. 
notion of theme as the 'starting point of the message', whatever theme is chosen for a sentence is a signal of how we would like people to understand what we mean. The theme is, then, a frame for understanding, inside which we should make sense and construct meaning. Moreover, language users choose to be theme of a clause or sentence the element that is most informationally appropriate at a specific moment in discourse, therefore, the thematic structure tends to reflect informational demands.

For a text to be fluent and well elaborated, it must follow an information distribution principle: there has to be some kind of alternation between old and new information in order for the communication flow to be established. The non-observation of this principle can negatively impact the text's communicative potential. Consequently, a text is considered well elaborated and easier to grasp, therefore more fluent, when old and new data flow smoothly in discourse. Rutherford (1987) gives the following example of a passage produced by a student:

1a) (1) My father's house had four bedrooms and two sitting-rooms. (2) A large garden was in front of the house. (3) My father had planted a lot of flowers in the garden. (4) These flowers were roses and tulips, etc... (RUTHERFORD, 1987, p. 69)

Comparing this passage with a second attempt by the same student, in which the only difference in relation to the first is the order of the information in (2) and (3), we have:

1b) (1) My father's house had four bedrooms and two sitting rooms. (2) In front of the house was a large garden. (3) In the garden my father had planted a lot of flowers. (4)

These flowers were roses and tulips, etc... (RUTHERFORD, 1987, p. 69)

The author argues that passage 1(b) is "more felicitous" in that it provides the reader with better ways to process the information conveyed, since the elements presented as rheme of a sentence almost always appear as theme of the next one. Consequently, in this passage, the flow of information is well-structured from the standpoint of the opposition between old and new data.

In this context, judging the adequacy of the information arrangement of a sentence on the discourse level does not mean judging its grammaticality. For example, in 1(a) sentences (2) and (3) are grammatical, but they are not the best links between (1) and (4).

As we have argued previously, meeting the cognitive/functional principle of information distribution means providing an alternation of old and new information in texts. This interplay between old and new information in texts requires knowledge of varied syntactic structures for making adequate choices of theme and rheme elements. From this perspective, the study of Clifton and Fraizer (2004) suggests that the presumed given-before-new preference may not be general, but can be limited to certain constructions, being also very biased on the language comprehension system and very sensitive to the requirements of language production, for example, doubled object and shifted noun group constructions. Similarly, Arnold et al. (2000) suggest that both 
grammatical complexity and discourse status influence constituent order, as they are both affected by constraints on planning and text production.

Overall, meeting this principle of information impacts the communicative potential of the text (PRINCE, 1981; HALLIDAY, 1985; 2004), since it results in texts that are more fluent and easier to comprehend.

Information structure, thematic structure and syntactic arrangements relate to our cognitive structure in terms of our processing capacities (CHAFE, 1990), as well as our capacity of attention. Patterns of attention distribution have been explained by cognitive linguists in terms of different degrees of salience or prominence of an element in discourse. The notions of focus and salience of perception are at the basis of the concepts of figure and ground. These concepts come from the Gestalt Psychology, and are found, in linguistics, in Hopper (1979), Langacker (1987; 2008), Talmy (2000), and many other authors. Figure is regarded as the most salient entity in a given configuration, while ground has secondary prominence.

Whatever use we make of sentences, we naturally foreground certain clause elements for attentional purposes. There are linguistic mechanisms for assigning attentional focus to certain elements, and the thematic structure constitutes one of the language systems or phenomena that reflect this interrelation between language and the cognitive capacity of attention ${ }^{2}$. The relation between the cognitive capacity of attention and language is pointed out and/or investigated by many authors, among others, Givón (1992); Landau e Jackendoff (1993); MacWhinney (1977); Osgood and Bock (1977); Langacker (1987; 2008), and Talmy (2000), who share the comprehension that the linguistic structure (syntactic positions) related to a certain scene will be influenced by the way the speaker distributes his/her attention among the elements that compose that scene. $^{3 .}$

In this perspective, attention and salience are intrinsically related to the thematic choice made by the speaker or the writer. In writing, MacCarthy (1991) has identified three different patterns of thematic structure. Writers very frequently compose texts that naturally fit one of these patterns. This happens due to the fact that people produce language that, from the cognitive point of view, is more adequate for processing purposes, since we have attention and memory limitations. The three patterns of text organization identified by MacCarthy (1991) are presented here:

(a) the theme of a sentence contains an element that becomes the rheme of the following sentence:

$\begin{array}{ll}\text { theme } 1 & \text { rheme } 1 \\ \text { theme } 2=\text { rheme } 1 & \text { rheme } 2 \\ \text { theme } 3=\text { rheme } 2 & \text { rheme } 3\end{array}$

\footnotetext{
2 A lot of psycholinguistic research that use referential priming and perceptual priming aimed at confirming the effect of visual focus on the choice of linguistic structural elements (TOMLIN, 1995).

${ }^{3}$ Other linguistic phenomena that specifically relate language to our cognitive capacity of attention are, for instance, topicalization and narrative structure. See Tenuta and Lepesqueur (2011) for this discussion.
} 
(b) the theme of a sentence has the same theme of the next sentence:

$\begin{array}{ll}\text { theme } 1 & \text { rheme } 1 \\ \text { theme } 2=\text { theme } 1 \_ & \text {rheme } 2 \\ \text { theme } 3=\text { theme } 1 \_ \text {rheme } 3\end{array}$

(c) the rheme of a sentence contains two elements that are taken as themes in the two subsequent sentences:

$\begin{array}{ll}\text { theme } 1 & \text { rheme } 1(\mathrm{a}+\mathrm{b}) \\ \text { theme } 2=\text { rheme } 1(\mathrm{a}) \_ & \text {rheme } 2 \\ \text { theme } 3=\text { rheme } 1(\mathrm{~b}) \_ & \text {rheme } 3\end{array}$

As one can see, there is a very significant interplay between thematic structure and information structure. Old and new elements, which structure the text informationally, are intertwined in the text flow via the participants of the verbal processes encoded in the message. The theme is usually a given element, and new information tends to appear as rheme. Therefore, when choosing the theme element for his/her proposition, the writer follows discourse principles for structuring information, i.e., he/she meets discourse pressures for the distribution of given/new information that makes the text more fluent, more easily comprehended. This discourse pressures are, thus, many times, translated into those thematic patterns presented by McCarthy.

There is a variety of syntactic resources available to writers and speakers of English to meet discourse pressures. Even though English is typologically considered an SVO language, there are several possibilities of rearranging the basic elements of the sentence (S, V, O/C, A). MacCarthy (1991) exemplifies various clausal arrangements involving fronting, i.e. various ways through which one can place different elements in the initial position of a clause. The author states that some of these structures are rarely found in pedagogical material or grammar books, for example:

3a) The Guardian, Joyce reads.

OSV Object-fronted

3b) Sometimes Joyce reads The Guardian.

ASVO Adverbial-fronted

$3 c)$ It is The Guardian Joyce reads.

$\mathrm{It}+$ be $+\mathrm{C} / \mathrm{O}+\mathrm{SV} \quad$ It-theme, or cleft

3d) What Joyce reads is The Guardian.

$\mathrm{Wh}+\mathrm{SV}+\mathrm{b}+\mathrm{C} / \mathrm{O} \quad$ Wh-pseudo-cleft

3e) She reads The Guardian, Joyce.

$\mathrm{S}$ (pronoun) VOS (noun) Right-displaced subject

(MCCARTHY, 1991, p. 51-52)

Differences in clause structure reflect different discourse demands in terms of information structure. Not all of the sentences above fit the same discourse contexts. 
3(a) could be a reply to "The Mirror, Lena reads. What about the The Guardian?" 3(c) or (d), alternatively, could be negative replies to "Joyce reads the Mirror, right? No..." Also, as we are going to point out later in this text, syntactic structures relate to attention and focus and we can see, in these examples, how distinct clause arrangements allow us to focus on different clause elements, through different degrees of salience: 3(a) says something 'about' The Guardian and 3(e) says something 'about' Joyce.

The subject of the clause is generally related to old information and it is the syntactic element that usually constitutes the immediate basis or the starting point for further development of the message. Chafe (1995) states that syntactic subjects carry light information load, which makes them appropriate for starting points. Although according to Chafe lightness does not necessarily imply givenness, this author presents the results of a study in which only $19 \%$ of subjects as starting points did not express given information.

From this perspective, syntactic subjects establish a starting point to which new information is added. For this reason, the information in them tends to have been active at earlier times in discourse. They are likely to be related to ideas previously active in the information exchange and are usually associated with the non-linguistic environment of the conversation (CHAFE, 1995). In Chafe's view, if a referent is identifiable, it is said to be active as a current focus of attention and awareness. If not active, it may be accessible, since it can be inferred from the situational or linguistic context, or made inactive if it is represented in long-term memory (CARROLL; SHEA, 2007). Subjects, therefore, tend to be active, conveying old information.

In this framework of analysis, the choice of which element will be taken as theme, for example, whether it is the subject or not, is based on communication demands. Therefore, when choosing the theme element of a proposition, the writer is following discourse principles of information structure in order to meet existing discourse pressures. Taking this interplay into account, it becomes evident how closely syntax, semantics and discourse are interconnected. Once again, in order to be able to meet several discourse pressures, the writer is required to produce diverse clause arrangements, or to realize syntactic movements, such as fronting, raising, extraction and extraposition, as stated by McCarthy (1991). These movements allow for different arrangements in the information distribution, while the propositional content of the sentences remains unchanged.

These different clause arrangements can be illustrated in the following examples:

4a) Martha brought the parcel yesterday.

4b) The parcel was brought by Martha yesterday.

4c) It was Martha who brought the Parcel yesterday.

4d) Yesterday Martha brought the parcel.

4e) Yesterday it was Martha who brought the parcel.

Though the semantic proposition remains the same in sentences 4(a) to (e), they present different elements as theme, generating different syntactic arrangements: the use 
of the passive voice, or the use of a cleft or a pseudo cleft, for example. Having diverse structures, those propositions do not all fit exactly the same communicative contexts. For example, in response to "What did Martha bring yesterday? Propositions 4(a) and (d) are the most suitable. In another context, 'What about the parcel?' choosing "parcel" as subject would be appropriate, for example, as in the passive structure 4(b).

Canale comments on the following example in Widdowson (1978):

5a) SPEAKER A: What did the rain do?

5b) SPEAKER B: The crops were destroyed by the rain.

According to Canale, B's reply is grammatical and sociolinguistically appropriate; however, it does not attach well to A's question, since there is violation, at the discourse level, of the normal organization of sentences in texts written in English in which the topic (shared information) precedes the comment (new information):

This principle of discourse restricts the grammatical form of utterances that can co-occur with A's question, filtering out compatible forms from incompatible ones, regardless of their grammaticality and sociolinguistic appropriateness. This interaction of grammatical, sociolinguistic and discourse rules is suggestive of the complexity of communicative competence. (CANALE, 1983, p. 10).

\section{LEARNERS' INTERLANGUAGE}

Rutherford (1987) analyzes some features of the learners' interlanguage of English as L2 and emphasizes the importance of working with learners to foster awareness of any major differences between interlanguage and target language forms. The interlanguage features discussed in Rutherford (1987) and checked in our researches are related to the syntactic resources and patterns that are important for users of English, if they are to be successful in producing texts that are: informationally well structured, sensitive to pressures of discourse and context, easily processed or understood, or even considered mature pieces of writing.

This need for becoming conscious of such grammatical aspects of the language system is especially recommended to adult learners, who have already gone through a process of formal instruction in L1 and can benefit from this metalinguistic approach to L2. This grammatical work can potentially make the acquisition of the writing skill easier. In relation to this point, we can check Richards's (1990) comment:

\footnotetext{
Whereas the rules of spoken discourse are acquired through conversation and do not require instruction, the rules of written discourse are largely learned through instruction and practice. [...] The goal of written language is to convey information accurately, effectively, appropriately; and to do this, written language has to be more explicit than spoken discourse (RICHARDS, 1990, p. 100-101).
} 
One of the characteristics of the interlanguage of learners of English as L2 lies in the fact that learners tend to place the constituents of the sentence in their basic position (basic SVO order) within an unmarked thematic structure of the clause, not applying syntactic movements of constituents. Learners tend to rely on an alignment between semantics and syntax, in which semantic relations are expressed directly within the canonical syntactic arrangement of the clause. However, fluency in any language implies, among other elements, the ability to be able to move the constituents of the sentence, generating non-direct correspondence between syntax and semantics, for example, through the use of passive voice in academic writing.

To be able to perform these kinds of syntactic changes and, therefore, to be better responsive to discourse pressures of a communication exchange, learners whose native language is Portuguese need to be taught, for example, that English requires a syntactic subject in any independent clause:

6. It is seven o'clock now; It is freezing today; $\underline{I t}$ is far from the main road; There is no problem.

Learners also need to be taught that fluency in English requires familiarity with syntactic changes generated by means of raising, fronting, extraction and extraposition. ${ }^{4}$ For example, from 7(a), a basic sentence (out of any discourse context), we can show the 'moved' structures (7.b, c and d), which resulted from the application of the types of movement mentioned:

7a) To detect such particles without a microscope is difficult.

7b) It is difficult to detect such particles without a microscope.

7c) Such particles are difficult to detect without a microscope.

7d) Without a microscope such particles are difficult to detect.

(RUTHERFORD, 1987)

In 7(b), we can say that we have extraposition: the element of which is difficult is predicate has been moved to the right of the VP and its previous place has been occupied by the "dummy $\underline{t}^{\prime}$. This resulting structure is common when the syntactic subject is complex, since it is easier to be processed. In 7(c), we have extraction and raising. The object of detect was extracted from the infinitive structure and raised to subject position. There are various types of raising: (S-O; S-S; O-S). In 7(d), we find fronting: the prepositional phrase without a microscope takes initial position.

In 7(a) syntax and semantics are 'aligned', while in 7(d) they are in maximum 'misalignment'. These types of movement, or these optional constructions, are also possible in Portuguese. Perhaps the greatest difference is that, in Portuguese, there is no

\footnotetext{
${ }^{4}$ The phenomenon that Rutherford and the more formalist tradition call syntactic movement, which generates one structure from another, in a more functional/cognitive tradition is dealt with in terms of different constructions (GOLDBERG, 1995; 1998). In essence, it is the same issue: In order to meet discourse pressures, can learners apply different syntactic movements to a basic sentence? In order to meet discourse pressures, can learners use different grammar constructions?
} 
obligatory syntactic subject in 7(b) - dummy it. It is important, however, to find out whether learners would use these alternative constructions in order to make their texts in English more fluent, or more easily processed. According to Rutherford, even when the learner's mother tongue allows for some type of movement, this learner may reject the moved structure in English. This goes hand in hand with what Canale (1983) states in relation to the teaching of communicative strategies:

\begin{abstract}
Although a general strategy such as paraphrase is indeed universal and used in first language communication, learners must be shown how such a strategy can be implemented in the second language. [...] Furthermore, learners must be encouraged to use such strategies... and must be given the opportunity to use them. (CANALE, 1983, p.11)
\end{abstract}

Therefore, those syntactic features and mechanisms should be highlighted in the learner's input and/or output.

Another issue related to the learners' interlanguage, which may be troublesome, concerns the semantic relations generated among the main verb of the sentence and its arguments (NPs). There can be several possibilities for NPs to be the syntactic subject and it is important for learners to get to realize those possibilities, since a change in the subject of the sentence may keep unchanged the relation between the verb and its arguments.

Non-agentive subjects is another linguistic resource available for English language users to conform to discourse pressures of information distribution in texts. For example, we can have grammatical syntactic subjects as agents, goals, or instruments:

8a) agent: The child broke the window with a hammer.

8b) goal: The window broke

$8 \mathrm{c})$ instrument: The hammer broke the window.

The production of non-agentive subjects by students is usually not very frequent (Rutherford, 1987). However, if made more frequent, it could result in more skillfulness for meeting the communicative demands of a given verbal exchange. Other examples of non-agentive subjects:

9. My guitar broke a string; This shirt buttons in back; Ice cream keeps for a long time; A dollar will not buy you much.

Another issue related to the development of learners' interlanguage may be illustrated by the following sentences:

10a) Rome invaded the island.

10b) The invasion of the island by Rome. 
The development of the interlanguage should enable learners to better elaborate their arguments, producing a more varied output. Again, specific contexts may demand the realization of verbal nouns and, it is necessary to make learners aware of this other licit linguistic strategy in which the change in the syntactic structure (from a to b) does not disturb the semantic relationships that hold among the lexical elements involved.

Another important feature of the interlanguage of L2 learners is lexical repetition. Concerning this matter, raising students' awareness of variations in lexical cohesion, e.g. synonymy, anaphora, and ellipsis, are thought to be very significant for the learning process.

In short, verb-argument relationships and lexical cohesion are key issues in grammar awareness for the global view of language as a vivid system for communication. According to Rutherford (1987), if one really wants to focus on syntax, semantics, and pragmatics as integral parts of a same whole, it is relevant to consider what one needs to do in terms of syntax to present a piece of information at position $\mathrm{X}$, and what kind of morphosyntactic changes are necessary to place or keep a certain lexical element in a specific linguistic context.

Rutherford (1987) favors Consciousness-Raising (CR), which is a grammaroriented approach that aims at helping learners become aware of the interconnections among syntax, semantics and discourse. In this perspective, grammar awareness is a means to an end and it involves combining metalinguistic knowledge in a contextoriented approach to grammar teaching.

The Noticing Hypothesis - NH (SCHIMIDT, 2001) is also a proposal in this regard. Schimidt has postulated that learners must meet to and, moreover, notice something in order to acquire it. NH therefore claims that learners' awareness of input is what becomes intake for learning. According to this proposal, learners perceive elements of the surface structure of utterances in instances of language, rather than from any abstract rules or principles of which such instances may be exemplars. The aspects of language which are noticed before others are considered more salient in their contexts.

Thus, information structure can be integrated into a set of assumptions about the processing of sentences in discourse, related to attention, and memory, which are cognitive functions. Information structure is, consequently, of potential significance for the learning of a language. The exercises designed for this study aimed at checking students' perception of the grammatical system, broadly speaking, involving its relation to discourse, and its impact to communication exchange and contextual meaning making.

\section{METHODOLOGY}

A set of ten exercises were designed to measure students' language awareness of the thematic and information structure in the clause. The exercises were administered to 46 undergraduate language students, majors in English, from a Brazilian Federal 
University (UFMG) and they were aimed at checking, specifically, perception by learners of:

a) the necessity of moving some components of the clause in order to meet particular discourse demands;

b) the relationship between the thematic structure and the syntactic structure of the clause; adequate reference and use of cohesive elements in a text;

c) appropriate clause structure in terms of SVO order and the necessity of a syntactic subject;

d) the fact that the same propositional content can be expressed through different nominal and verbal structures and

e) the grammaticality of sentences with subjects performing different thematic roles.

In order to achieve these purposes, the exercises proposed to the students aimed at verifying whether students recognized implicitly (procedurally) and/or explicitly (declaratively) ${ }^{5}$ the existence of the thematic and information structures of sentences. The exercises checked a basic research question that could be stated as follows: Are students aware of the principle of information distribution in language? Apart and related to this principle, the exercises also checked the mastering by the learners of various syntactic devices, which are used to meet discourse demands in terms of informational and thematic structure, and which reflect the relation between language and cognition through processes of attention and focus. The following types of exercises were designed:

a) Given/new principle exercises: to check perception of the need to move sentence constituents to meet discourse pressures.

b) Cohesion exercises: to check perception of adequate establishment of correference, as well as to check identification of appropriate cohesive devices of a given referent.

c) SVO order exercises: to check perception of a problem with the structure in terms of its SVO order.

d) Propositional cluster exercises: to check perception of the fact that the same propositional content can be expressed through different nominal and verbal structures.

e) Theme presentation exercises: to check perception of changes underway when a thematic element is made available through different syntactic arrangements in clause structure.

f) Non-agentive subject exercises: to check perception of the grammaticality of sentences with grammatical subjects performing different thematic roles.

The exercises were proposed and learners' responses were analyzed and categorized in terms of the main research aims.

\footnotetext{
${ }^{5}$ The declarative and procedural knowledge are concepts found in Johnson (1994). 
In the next section, there are a few samples of those exercises, learners' responses to them, and the kinds of findings they provided researchers with.

5 DATA ANALYSIS

In this section, we present the data collected in the study. We focus our analysis on the following topics: information and thematic structure interplay; subjects performing various thematic roles; mandatory syntactic subject; cohesive elements; same propositional content expressed through different thematic arrangements; propositional clusters and nominalizations.

\subsection{THE INTERPLAY OF INFORMATION AND THEMATIC STRUCTURES}

The following exercise was administered to research participants in order to check the interplay between thematic and information structures in a text.

11. Which passage below is of easier understanding (more fluent reading)?

a) ( ) The late English artist and filmmaker Derek Jarman once met a friend on London's Oxford Street and complimented him on his beautiful yellow coat. His friend replied that he had bought it in Tokyo, where it was not considered yellow at all, but green.

b) ( ) The late English artist and filmmaker Derek Jarman once met a friend on London's Oxford Street and complimented him on his beautiful yellow coat. In Tokyo, where his friend bought the coat, it was not considered yellow at all, but green.

(In: www.bbc.com/future/story/20120427)

In this regard, 34 respondents (74\%) marked the correct option (passage a): old information alternating with new information (more appropriate information structure). This is still considered a low score, taken that there was a $50 \%$ chance of getting the answer right (since there were only 2 options).

In Tenuta (2001), a larger number of options resulted in less correct choices (67.2\% - two options, and 46.1\% - three options). The author pointed out that there was recognition of the principle of information distribution in discourse by the learners (part of their implicit knowledge); however, it was meaningful the fact that more options disturbed their perception of this principle.

In the current research, only $13 \%$ of the learners were able to adequately explain their choice. In 2001, we had a very similar situation, since few students could explain adequately their options (12.4\%).

Both these studies revealed that explicit knowledge of the principle was not significant among the participants. Undergrads showed, therefore, little metalinguistic knowledge of the matter, which can be considered a shortcoming, since they were all English majors. 
As for the perception, by learners, of the grammaticality of sentences with subjects performing different thematic roles, the students tended not to be able to realize the grammaticality of sentences such as:

12a) This purse buttons back.

12b) My keyboard broke a key.

Only $13 \%$ of the students accepted the grammaticality of sentence (a), and $32 \%$ of sentence (b). Even though the syntactic subjects in these sentences are not agents, they are acceptable in English and students failed to recognize that. These findings reveal that students were not very familiar with different subjects performing different thematic roles and that they were probably more likely to use only agentive subjects, even in a context that required a non-agentive subject as theme.

These results go in the same direction of what happened in the 2001 study. Tenuta (2001) reports that sentences with non-agentive subjects that had a direct correspondent form in Portuguese (literal translation) were accepted more easily as grammatical $(76,3 \%)$ than those that did not $(41,6 \%)$.

\subsection{MANDATORY SYNTACTIC SUBJECT}

Concerning the ungrammatically of sentences that lack a syntactic subject, we used the following passage in the exercises:

13. In Brazil are many cities to visit. One of them is Belo Horizonte. Is here where is going to be one of the places that Brazil team will play during the World Cup.

A figure of $33 \%$ indicates the percentage of students that could not identify the source of ungrammaticality for this passage containing sentences without a syntactic subject. This can be considered a high percentage for such a basic feature of the English language and the students' learning level.

Nearly half the students noticed that the text had sentences that lacked syntactic subjects $(56.4 \%)$ in Tenuta (2001). This was considered a low percentage of right responses to the exercise, especially taking into account that these learners, as the ones checked in our current research, had already had a long period of formal instruction in the target language.

\subsection{COHESIVE ELEMENTS}

As for cohesive devices, learners also had problems identifying specific units as cohesive elements in the text. For example, in the passage: 
14. [...] So where does this leave the traveler who wants a place with a comfy bed... (this refers to a situation described before in the text).

In this regard, only $5 \%$ of the students were able to come up with the correct indication of the part of the text to which the underlined pronoun referred. This means that the identification of cohesive elements referring to a broader portion of a text may represent an obstacle to learners, probably impacting their understanding of a text.

In the study carried out in 2001, students had two tasks to do in relation to cohesiveness. When they were asked to find the referent of a specific element, they got better results $(71.8 \%)$ than when they had to point themselves the elements that had referents in the text $(46,9 \%)$. This makes evident the fact that we still need to work to raise students' consciousness of the interrelation of cohesive elements in texts, to help them produce texts that are more fluent and better structured from the point of view of information distribution.

In more mature pieces of writing, given, or previously referred, elements do not usually reappear simply as repetitions, they come in a variety of forms (nominal, pronominal, verbal, ellipsis), i.e. these varied forms have similar referential content to a previous linguistic occurrence and students must be prepared both to identify and to produce them.

\subsection{SAME PROPOSITIONAL CONTENT EXPRESSED THROUGH DIFFERENT THEMATIC ARRANGEMENTS}

Focusing on the following sentences

15a) Someone took it to my classroom.

15b) It was taken to my classroom.

we checked students' awareness of the fact that the same propositional content can be expressed through different thematic arrangements, in different syntactic structures. Regarding this issue, $47 \%$ of the participants could identify the syntactic changes in those sentences: These findings reveal that approximately half the students in our current research were able to explain the changes using appropriate metalanguage for it. This also means that the other half of them were not able to come up with such an explanation.

In Tenuta's (2001) study, 59\% of the students were able to explain that the change in the thematic arrangement of the clause resulted in the restructuring of it into a passive construction.

When learners were asked to choose between those two sentences to place in a specific linguistic context, $72 \%$ of them made the most appropriate choice in terms of the principle of information distribution. Even though the majority seemed to be aware of the impact that these different clause arrangements may produce in discourse, we still had a significant number of students that do not notice this situation, especially if we 
consider that they had $50 \%$ chance of getting it right, being only two alternatives presented.

Between the two options that students had in the exercise done in 2001, 76,9\% of them made the appropriate thematic choice; however, most of these students seemed not to have explicit knowledge of the issue, since only 15,4\% could explain the reason for their choice. In this case, we claim that explicit knowledge results in better chances for students to make appropriate thematic choices.

\subsection{PROPOSITIONAL CLUSTERS AND NOMINALIZATIONS}

The propositional cluster exercises in this research were composed of a few lexical items and instructions that, first, led the student, using formulas, to create nominalyzed structures containing all of those items in various thematic arrangements. This step of the activity aimed exactly at raising some sensitivity concerning different possibilities of expression of similar propositional content. For example:

16a) Ann clean room broom

Possible outcomes are:

16b) Ann's cleaning of the room with a broom; the room's cleaning with a broom by Ann; a broom cleaning of the room by Ann.

As a second step for the activity, in order to complete the exercise, the participants were asked to choose one of the nominalizations created to fit a specific linguistic context.

$39 \%$ of the participants made the most appropriate choice, because they considered, even if implicitly, the elements of the previous text and the thematic structure in the nominalized structure for a good distribution of information. However, only $2 \%$ of those participants could provide a reasonable explanation for their choice, i.e., very few learners presented some explicit knowledge of the information principle.

When analyzing prepositional cluster exercises, Tenuta (2001) counted the number of nominalized structures produced against the number of structures that did not involve nominalization. As a result, the author identified an inferior production of structures with 'verbal nouns' (nominalizations) than with clause structures. Also, in her study, she identified a lot more active than passive clauses. With those results, we can infer that these learners will probably not be able to use 'verbal nouns' in their texts, which means having less linguistic resources for making good thematic choices. 
Findings in this research confirm results in (TENUTA, 2001). They point to the fact that the majority of the analyzed undergraduate English majors at an intermediate or post-intermediate level of proficiency do not generally have explicit knowledge of the principle of information structuring in discourse and have rather little implicit knowledge of this principle. Results also showed that these learners presented some of the characteristic discussed by Rutherford as being common to learners of English as L2: first, they had some difficulty establishing correferentiality of cohesive elements; second, only approximately half of the learners were able to identify that some sentences lacked a syntactic subject, which is mandatory in English; finally, they recognized few non-agentive subjects as grammatical, which reduces their chances of fully meeting discourse pressures in some contexts, not being able to use varied thematic elements when producing their messages. Other researches would have to be done, in other Brazilian academic settings, but we hypothesize that the situation might not be different elsewhere.

From this viewpoint, L2 Learners, being non-native speakers, do not always seem to perceive how information is better distributed in order to be faithful to the salience of elements in certain linguistic contexts. On the other hand, when they do seem to notice those aspects of salience and focus, they are not equipped declaratively to talk about such processes involved in sentence construction or interpretation. This becomes evident for, in both researches (2001 and this one), learners were often unable to adequately explain what changes were made in different linguistic arrangements.

We are here focusing on a complex grammatical system, which has grammar related to discourse and to cognition. In this perspective, verbal interactions within a context of use emerges from the way the organization of speech itself relates to or is somehow dependent on human cognitive capacities. At the time of Tenuta's (2001) study, learners needed to be made more conscious of the fact that discourse demands affect syntax; they were not aware of the nature of both this relation between syntax and discourse, and the relation of those systems to cognition. Learners seem still mostly unaware of these facts, according to the results presented here.

A great deal of language teaching practice is founded on the premise that learners can master different aspects of the target language. Their learning can be improved, however, if they are led to notice those aspects. Considering that there are languagespecific, or linguistic typological differences, one of the important functions of teaching is to help learners focus their attention on aspects of the mother tongue that differ from their native language. Learners, nevertheless, should also be made aware of linguistic aspects that are ruled by rather universal principles, especially those of a cognitive nature, such as the information distribution principle focused in this paper. As Rutehrford (1987) points out, learners may use some syntactic form or movement in his/her mother tongue, but not do it in the target language, perhaps because they do not feel secure and prefer to rely on more basic or unmarked structures.

In this regard, the pattern of information distribution is not language specific and can probably be generalized to all or most languages, being a language-general 
tendency (Rutherford 1987, p. 113). Therefore, even occurring in Portuguese (L1), it is necessary to get to know if such pattern has to be learned or re-learned in L2.

Besides favoring promotion of linguistic practice on variations of target language forms that may allow learners to cope with distinct discourse demands, we reinforce the notion that metalinguistic awareness should also be object of language instruction. This instruction is a way to further develop learners' skillfulness to better respond to communicative demands. Particularly in the case of English majors, promoting explicit or declarative knowledge of the English language system and its constitutive rules is important, since these learners will most likely be language professionals and will work as teachers or researchers in some area of linguistics. In this perspective, we should deal with grammar as a part of a system that is integrated to discourse, and we should also approach the user's choice of linguistic forms as somehow conditioned to functional and cognitive restrictions. This way, we will be able to reflect about and get to know reasons behind rules and relations among linguistic elements and phenomena.

This study could be expanded in a few directions, especially to include investigation of the way the same learners of English as L2 deal with this broad issue of the interrelation of syntax, discourse and cognition in their mother tongue.

\section{REFERENCES}

ARNOLD, J. E. et al. Heaviness vs. newness: The effects of structural complexity and dis course status on constituent ordering. Language, 76, p. 28-55, 2000.

CANALE, M. From communicative competence to communicative language pedagogy. Language and communication. Longman, 1983. 288 p.

CARROLL, S. E.; SHEA, C. Salience, focus and second language acquisition. Nouveaux cahiers de linguistique française, 28, p. 99-106, 2007.

CLIFTON, C. J. R.; FRAIZER, L. Should new information come before new? Yes and NO. Memory and Cognition, 32, p. 886-895, sept. 2004.

CHAFE, W. Some things that narrative tells us about the mind. B. K. Britton; A. D. Pellegrini (Eds.) Narrative thought and narrative language. New Jersey: Lawrence Erlbaum, p. 79-98, 1990.

. Discourse, consciousness and time: the flow and displacement of conscious experience in speaking and writing. Chicago, Ill: University of Chicago Press, 1995. 392 p.

GOLDBERG, A. E. Constructions: a construction grammar approach to argument structure. Chicago: University of Chicago Press, 1995. 265 p.

Semantic principles of predication. Discourse and cognition: Bridging the gap. JeanPierre Koenig (Ed.) CSLI Publications, p. 41-55, 1998.

GIVÓN, T. The grammar of referential coherence as mental processing instructions. Linguistics, 30, p. 2-55, 1992.

HALLIDAY, M. A. K. An introduction to functional grammar. London: Arnold, 1985. 387 p. . An introduction to functional grammar. London: Hodder Arnold Publication, Revised Edition, 2004. p. 689.

HOPPER, P. J. Aspect and foregrounding in discourse. T. Givón (Ed.) Syntax and semantics. New York: Academic Press, p. 213-241, 1979.

JOHNSON, K. Teaching declarative and procedural knowledge. Grammar and the second language teacher, Prentice Hall, UK, p. 121-131, 1994. 
LANDAU, B.; JACKENDOFF, R. What and where in spatial language and spatial cognition. Behavioral and brain sciences, Cambridge University Press, 16, p. 217-261, 1993.

LANGACKER, R. W. Foundations of cognitive grammar: Theoretical prerequisites. Stanford, CA: Stanford University Press. v. 1, 1987. 540 p. $567 \mathrm{p}$. Cognitive grammar: a basic introduction. New York: Oxford University Press, 2008.

MacCARTHY, M. Discourse analysis for language teachers, Cambridge University Press, 1991. p. 213.

MacWHINNEY, B. Starting points. Language, 53, p. 152-168, 1977.

OSGOOD, C. E.; BOCK, J. K. Salience and sentencing: some production principles. S.

Rosenberg (Ed.) Sentence production: developments in research and theory. Hillsdale, NJ: Erlbaum, p. 89-140, 1977.

PRINCE, E. F. Towards a taxonomy of given-new information. P. Cole (Ed.) Radical pragmatics. New York: Academic Press, p. 222-255, 1981.

RICHARDS, J. C. The language teaching matrix, Cambridge University Press, 1990. 185 p.

RUTHERFORD, W. Second language grammar: learning and teaching. Essex: Longman, 1987. $208 \mathrm{p}$.

SCHMIDT, R. Attention. P. J. Robinson (Ed.) Cognition and second language instruction. Cambridge, U.K., p. 3-32, 2001.

TALMY, L. Toward a cognitive semantics: concept structuring systems. Cambridge, MA: The MIT Press. v. 1, 2000. 569 p.

TENUTA, A. M.; LEPESQUEUR, M. Aspectos da afiliação epistemológica da Linguística Cognitiva à Psicologia da Gestalt: percepção e linguagem. Ciências \& Cognição, v. 16, n. 2, p. 65-81, 2011.

TENUTA, A. M. A estrutura da informação no discurso e algumas caraterísticas da interlíngua de aprendizes de língua inglesa como L2. Linguagem e Ensino, v.4, n.2, p. 11-34, 2001.

TOMLIM, R. S. Focal attention, voice, and word order: an experimental, cross-linguistic study., P. Downing; M. Noonan (Ed.). Word order in discourse. Amsterdam: John Benjamins, p. 517$554,1995$.

WIDDOWSON, H.G. Teaching language as communication. Oxford: Oxford University Press, 1978. $168 \mathrm{p}$.

Recebido em: 09/08/14. Aprovado em: 03/03/15.

Título: O princípio funcional/cognitivo da estrutura da informação em textos: pressões discursivas e mecanismos sintáticos para aprendizes de inglês como L2

Autores: Adriana Maria Tenuta; Ana Larissa Adorno Marciotto Oliveira

Resumo: Este trabalho apresenta resultados de um estudo realizado com a finalidade de se investigar o grau de percepção da estrutura temática da oração (tema e rema) e da estrutura informacional de um texto (elementos dados e novos) por aprendizes brasileiros de língua inglesa. O estudo tem por embasamento teórico os princípios da linguística funcional-cognitiva, relativos à maneira através da qual o discurso influencia as escolhas linguísticas gramaticais (HALLIDAY, 1985; CHAFE, 1995). O corpus da pesquisa consistiu de uma série de exercícios que foram aplicados a estudantes de graduação em Letras, com habilitação em Inglês, de uma Universidade Federal no Brasil. Os resultados lançam luz sobre o fato de que esses aprendizes não estão ainda muito cientes de vários processos envolvendo arranjos gramaticais e o fluxo do discurso, da mesma forma que também não percebem muito bem como a gramática pode impactar a intenção comunicativa de um texto escrito.

Palavras-chave: Tema e rema. Dado e novo. Discurso. 
Título: El principio funcional/cognitivo de la estructura de información en textos: presiones discursivas y mecanismos sintácticos para aprendices de inglés como L2

Autores: Adriana Maria Tenuta; Ana Larissa Adorno Marciotto Oliveira

Resumen: Este trabajo presenta resultados de un estudio realizado con la finalidad de investigar el grado de percepción de la estructura temática de la oración (tema y rema) y de la estructura informacional de un texto (elementos dados y nuevos) por aprendices brasileños de lengua inglesa. El estudio tiene por basamento teórico los principios de la lingüística funcional-cognitiva, relacionados con la manera a través de la cual el discurso influencia las elecciones lingüísticas gramaticales (HALLIDAY, 1985; CHAFE, 1995). El corpus de la investigación fue estribado en una serie de ejercicios que fueran aplicados a estudiantes de graduación en Letras, con habilitación en inglés de una Universidad Federal en Brasil. Los resultados iluminan el facto de que los aprendices no están todavía mucho conscientes de varios procesos involucrando disposición gramatical y flujo del discurso, así también no perciben muy bien como la gramática puede impactar la intención comunicativa de un texto escrito.

Palabras-clave: Tema y rema. Dado y nuevo. Discurso.

TENUTA, Adriana Maria; OLIVEIRA, Ana Larissa Adorno Marciotto. The functional/cognitive principle of information structure in texts: discourse pressures and syntactic devices for English as L2 learners.

Linguagem em (Dis)curso - LemD, Tubarão, SC, v. 15, n. 1, p. 117-135, jan./abr. 2015. 